\title{
Citizens' participation in financing national projects (an applied study on the enlargement of the Suez Canal of Egypt)
}

\author{
Zeinab Abbas Zaazou \\ MIS Department, Faculty of Management Sciences, \\ October University of Modern Sciences and Arts (MSA), Cairo, Egypt
}

Financing national projects

Received 11 October 2019 Revised 20 January 2020 Accepted 2 March 2020

\begin{abstract}
Purpose - The purpose of this study is to analyze the relationship between citizen participation and the level of trust in government's decisions and policies; as well as examining the impact of disclosure of information on the level of citizens' engagement with governments' projects. In addition, testing the real motives behind Egyptian citizens' participation in financing national projects. The study is applied to the "New Suez Canal," which was finished in only one year opposing the three years implementation period suggested by some studies.
\end{abstract}

Design/methodology/approach - The researcher depended on secondary and primary data as well in working on this paper. She used secondary data gathered from scholars and from domestic and international institutions. Then, she conducted a field study and collected data through distributing 384 Likert Scale questionnaires containing 34 self-administered among respondents to test the following: 1. Citizens perceptions regarding the level of trust in government's decisions and policies. 2. The impact of citizens' trust on their willingness to participate in governments' projects. 3. Is 'public service motivation' (PSM) behind citizens' willingness of participating in national projects. 4. Is the 'high expected profit of Suez Canal Investment Certificates' behind citizens participation in national projects.

Findings - $H 1$ and $H 2$ have been accepted as trust, transparency and citizen participation proved to be important pillars of building a participatory government. Moreover, citizens' participation in national projects encouraged national and international enterprises to invest in the canal provision. $H 3$ and $H 4$ are accepted and the statistical study revealed dual contradicting results regarding the motive of citizens' financial participation in the New Suez Canal project. The justification for the contradiction is that right after the 2011 up-rise, Egyptian citizens were overwhelmed with patriot emotions and feelings pushing them to participate in national projects. At the same time this patriot drive was moderated by the "performance-based rewards and citizens" self-interests' pushed by the Egyptian government (offering a high-interest rate for Suez Canal Certificates at that time). Citizens might be motivated to participate in national projects triggered by many factors: public service drive - patriotism or self-interest.

Research limitations/implications - The study needs further deeper investigation and empirical pieces of evidence to answer the following questions: would different participatory actions result differently in other circumstances? Do individuals' levels of PSM vary over time? Besides, the researcher needs to find ways to test PSM against various motives such as self-interest, which needs to be confirmed empirically.

Practical implications - The author came up with important recommendations for central government and decision-makers in Egypt and is based upon the study's statistical results. The most important recommendations were: central government and decision-makers should frame a policy

(C) Zeinab Abbas Zaazou. Published in Review of Economics and Political Science. Published by Emerald Publishing Limited. This article is published under the Creative Commons Attribution (CCBY 4.0) licence. Anyone may reproduce, distribute, translate and create derivative works of this article (for both commercial and non-commercial purposes), subject to full attribution to the original publication and authors. The full terms of this licence may be seen at http://creativecommons.org/ licences/by/4.0/ legalcode

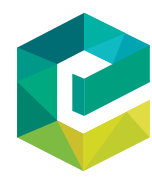

Review of Economics and Political Emerald Publishing Science e-ISSN: 2631-3561 DOI 10.1108/REPS-10-2019-0131 
designed to promote citizens' participation in decision-making drawing on the guidelines for civil participation in political decision-making. Decision-makers in the central government should work local and regional authorities to update and improve local and regional regulations concerning the participation of citizens in local public life and promote a culture of democratic participation shared by communities and local authorities. Performance-based rewards (high-interest rate) are moderating the citizens' public service motivation (PSM - patriot sense) and citizens may be motivated by different factors such as public service drive - patriotism or self-interest.

Social implications - The study is tackling an important issue, which is civil participation in political decision-making. It is also discussing promoting cultural awareness regarding the importance of democratic participation shared by communities and local authorities. The study came up with certain findings proving Egyptian civil society's willingness in participating with the government in national projects; believing in its socio-economic benefits.

Originality/value - Finally, the study is of value, as it could be considered a pilot study representing the outcomes of citizen participation in national projects; in addition, it can be considered as a road map to policymakers. Moreover, the findings provide a set of recommendations and policies for governments and decision-makers to undertake tangible actions to accelerate citizen participation in further projects and decisions and be able to establish a democratic system in developing countries.

Keywords Citizen participation, Public service motivation, Disclosure of information, National projects, Performance-based rewards

Paper type Research paper

\section{Introduction}

The democracy and governance framework demands each nation to include its citizens in decisions related to public policies and development projects and programs. As interpreted by some authors, the difference between "governmental and public policies lies in the capacity of public involvement in governments" decision-making and policy-making processes (Dutrénit and Suárez, 2017). Due to the rapid change happening in the international society in terms of science, technology and innovation, public participation in policy-making became essential in developed and developing countries as well. Furthermore, due to the heterogeneity of the public in communities nowadays and in policy actors and global links, it became highly recommended to involve the public in countries' policymaking processes specifically in the field of science, technology and innovation.

There is no doubt regarding the weight and importance of the public sector as a driving force of economic growth through minimizing government budgets, sharpening their competitive advantage and delivering public goods and services with new approaches and innovative nature. Of course, all that will be easier accomplished with greater citizen participation whether by designing public policies and decisions or by financial participation in development projects and programs.

In the following section the researcher presents through various theoretical perspectives different arguments regarding the impact of transparency and disclosure of information on increasing citizens' trust in their government; how can the establishment of the Political Culture lead to liberal democracy, which leads to citizen participation. Furthermore, the impact of performance-based rewards and public service motivation (PSM) on citizens' participation in governments' policies and projects and how it can weaken and moderate the initial drive of citizens' participation in government's policies and strategies. Finally, the literature tackled the issue of "financial citizenship (FC)" as elites and citizen investors can play distinctive contingent roles in FC especially in the stock market.

The second section discusses the historical review of the Suez Canal and presents the unique Egyptian experience of co-funding the national project of the "The Enlargement of Suez Canal" in 2014. 
The third section contains the field study conducted by the researcher regarding the experience of citizen participation in financing the project of enlargement of the Suez Canal in Egypt; as well as the field study results, analysis, conclusions and recommendations.

Financing national projects

\section{Research hypotheses}

H1. Transparency and disclosure of information increase the level of citizens' trust in their government.

H2. Citizens' trust in their government increases the level of participation in national projects.

H3. The PSM (Patriot Drive) is behind Egyptian Citizens' participation in financing the New Suez Canal

H4. The High expected profits of the Suez Canal investment certificates was the driving force behind citizens' participation in the New Suez Canal project.

\section{Literature review}

Citizen participation definition

Although there is no universal definition of citizen participation, most studies refer to the ladder of citizen participation established by Arnstein (1967) [1]. This ladder shows three dimensions of citizens' participation:

(1) information-sharing, which means providing open-spaces to share public demands and a government decision process. Citizens will be able to monitor the mechanisms of public decisions and governments will be able to acquire information about public demands in implementing public policies;

(2) collaborative policy-making; and

(3) collaborative decision-making (Yang and Callahan, 2007) [2].

Citizens' drive for national participation: transparency and disclosure of information, citizens' trust in their government

Many authors assure that democracy, transparency and citizens' participation increase the level of confidence in the government. Some experts say that there is a direct relationship between corruption and trust and when public officials are corrupted citizens develop automatically distrust of the government and the whole society (Rothstein and Stolle, 2003).

Dut u and Diaconu (2017) stated that "transparency" can be considered as a first step in opening the local public administration.

Many authors believe that "transparency" is the proof and base of any government's integrity, citizen empowerment and accountability. Moreover, a high degree of "transparency" can reduce the gap between citizens and their government and enhance the quality of public decisions (Kim and Lee, 2017).

According to Abelson and Gauvin (2006), previous studies have proved that knowledge availability and increased levels of interest enhanced the social bond and trust between citizens and their government. 
Participatory policy making definitely narrows the gap between government and citizens, improves the quality of governments' decisions and strengthens the problemsolving capacity (Michels and De Graaf, 2010).

According to Carreira et al. (2016), if citizens are satisfied with the outcome of their public participation and feel positive about participating in public policy decisions, their trust in the policymakers and their level of public participation will increase.

Lee and Park (2009) stated that many governments in Asia and Europe attempted to expand the level of disclosure of information and enhancing access to it. Moreover, they worked hard to improve the regulations and the integrity of public officials, strengthening the responsibility of local governments and increasing the level of transparency and credibility of local financial management.

Transparency is a mandate when it comes to the government's trust; citizens' exposure to qualified correct information is essential for building a bridge of trust between government and citizens.

\section{E-government increases citizens' trust}

Citizens' exposure to information related to e-government, makes them believe that the government is capable of solving problems. E-government has been proposed as a solution for increasing citizen communication with government agencies and, ultimately, political trust. They claim that e-government is one of the vital tools for increasing citizens' participation with government entities and overcoming the gap of trust (Kim and Kim, 2007).

According to Blakeley (2010), citizens' participation via e-government channels is a topdown control and is focusing only on the area of service delivery and not really empowering citizens and giving them real opportunities to participate in decision-making.

In a democratic society of the postindustrial digital age citizen participation in policymaking is the best option for problem-solving, yet practically speaking facilitation of public meetings has many challenges regarding motivating citizens to get engaged in public issues and coming up with creative problem solutions (Brabham, 2009).

\section{The establishment of the political culture leads to liberal democracy, which leads to citizen participation}

According to Almond and Coleman (1960), civic culture is a culture of consensus and diversity; it is a mix of humanistic and scientific-technological culture.

The political culture derives from the civic culture and to be able to characterize a nation's political culture, we should consider different kinds of cognitive, affective and evaluative orientations toward the political system of the country in general and its input and out elements and finally, the citizen as a political actor.

Gabriel and Coleman then explained the "cognitive" aspect of the political culture by saying that this is about the amount of knowledge a citizen has about his nation and political system. As for the "effective" aspect of the political culture, they clarified that this is about the amount of knowledge a citizen has regarding the structures, the roles, the various political elites and policy-making strategies. Finally, they tackled the "evaluative" aspect of the political culture, saying that it is about the knowledge a citizen has regarding his/her rights, powers, obligations and influence accessibility. Furthermore, it is about how he/she perceive themselves as a member of their political system.

To be able to understand all about democratic culture diffusion in a society, we have first to develop appropriate measures for it to discover how much should be diffused before democratic institutions embrace and apply certain attitudes and expectations. If we take Britain's experience of democratic culture diffusion among society, we will find out that it goes 
back to the industrial revolution time. At that time, aristocrats entered a coalition with merchants and industrialists for the sake of establishing the principles of parliamentary supremacy and representation. Britain succeeded to attain national unification and to tolerate an autonomy of aristocrats, local and corporate way more than Europe. It is obvious that the British instilled the democratic culture bit by bit, as the industrial revolution and took it in steps such as separation from the Church; the emergence of merchants, the involvement of court and aristocracy in trade and commerce, etc. To conclude democratic culture should be instilled within a society gradually (Gabriel A. Almond and James Coleman, 1960).

Fuchs and Roller (1994) argued that the road to liberal democracy is long and takes a lot of effort, time and money to be successfully implemented. It starts with the establishment of the right political culture, which consists of two dimensions: the structural instilled values and beliefs of democracy and the community's high commitment to implement these values as it is very important that the members of the community feel bound by it. The more the community shows compliance and commitment to these values, the stronger the institutionalization of values will be. The same goes for political structure: if the community legitimizes the structure, the political structure will be institutionalized. However, the way in which decision-makers act is a key factor for citizens' acceptance and conformity with the rules. If the political elite violates constitutional norms, this leads to citizens' negative evaluation of the performance of democracy.

According to Park (2016). A country's political culture and the variation in the forms of government is determining the level of citizens' participation adoption in the budget process.

Lussier (2011) argued that instilling a new democratic system into a country's political system encourages citizens to interact with elites and others and provides opportunities for civil society to engage politically in ways that were considered impossible before the transition to democracy. Although, we can not ignore the role of the contingent events, which can cause a reverse in the democratic transition phase and the country may go back to its old authoritarian system. A realistic example: after Russia's initial democratic transition it failed to expand political participation.

According to Hobson (2009), democratization (democratic transition) must be internally generated and sustained. Once citizens rose up demanding societal, economical and political reform and change, the external actors can provide various forms of aid programs, also supplying funding, providing training, logistical support to opposition groups and ensuring the presence of election monitors.

\section{Public service motivation and performance-based rewards}

Pandey and Stazyk (2008) stated that PSM drives individuals to value and prefer serving society over monetary rewards. While Brewer et al. (2000) defined PSM as a citizen's intention to respond to motives initiated by public institutions. PSM is derived from three bases, namely, rational, norm-based and affective. The rational motives are operative when individuals are convinced and committed to certain public programs. Norm-based motives are reflecting an individual's desire to serve the public interest due to patriotism, duty and loyalty to the government. Finally, the effective motives are characterized by the willingness to help and support others; it is grounded in human emotion. An individual may have a mixture of the three motives that contribute to his/her behavior.

Lee et al. (2019) explained that trust has a profound impact on PSM. An organization with high-trust culture is related to directly to loyalty and PSM. Trust in leaders and top management helps reduce various barriers and attain more positive outcomes; it revives the PSM feelings among individuals. Trust in leaders cultivates individuals' PSM and drives them to be active members of their society and participate in decision-making.
Financing national projects 
According to Epstein et al. (2018), performance-based rewards indicate to employees the consequences of certain actions and provide incentives to employees to push them toward an appropriate response.

Huang and Feeney (2016) assured that performance-based rewards and PSM are playing a role in pushing citizens toward participating in government decision-making and found out that citizens' initial will of participation in governments' decision-making (PSM) can be moderated by performance-based rewards initiated by the government itself.

\section{The Egyptian liberalism prior and post the 2011 revolution}

Fahmy and Faruqi (2017) stated that the Egyptian liberalism has some understanding of secularism, although the liberal project's outcomes, in general, were full of contradictions. Taking Egypt's case, we will find that the Arab and Islamic heritage played a big role in this regard. Egyptians do favor a democratic government, but on the other hand, many of them do not believe in women's equality to men and many Egyptians feel that the legal system should follow the Quran. These contradictions require that we put into consideration the Egyptian institutional, social and intellectual context in which liberalism works.

Robert Forster (2017) stated that the chosen date of protest in 2011 (the national police holiday) reflected rights-based grievances regarding the social and political conditions in Egypt at that time. These grievances could be summarized in the 31-year state of emergency, police brutality and the ethnic and religious minorities. In addition to the social, economic and political exclusion of youth, women and Egyptian lower classes. Furthermore, the ruling National Democratic Party practiced a strict monopoly on election ballots and on political power as well. These circumstances gave the banned Muslim Brotherhood organization the opportunity to take responsibility for health, educational, civil and religious organizations regardless of the civil society restrictions set by the Ministry of Social Solidarity. Finally, the prospect of hereditary rule and a transfer of power to Hosni's son, Gamal Mubarak the prospect of hereditary rule and a transfer of power to Hosni's son, Gamal Mubarak created an atmosphere of dissatisfaction among Egyptians. Moreover, dissatisfaction feelings spread among military elites because of the US restrictions on Egypt's arms purchases to ensure that Egypt could not compete with Israel's military.

A political controversy from 2011-2014 continued between state institutions and elected officials and was extended to the constitutional drafting process. It was a period, which witnessed three Constitutional Assemblies (CAs), two referendums on two constitutions and four constitutional declarations. After Morsi stepped into the office in 2013, he reinstated the parliament until new elections were announced and demolished the SCAF's constitutional declaration issued just a few days before he became president. Within six months, the Supreme Court, consisting of Mubarak-era judges, dissolved the Parliament in what the Islamist bloc considered a "coup" This political turmoil hindered any attempts of comprehensive institutional reform (Hearst and Hussein, 2012).

\section{Suez Canal historical overview}

The Suez Canal has seen much conflict and attention from large powers due to its strategic positioning between three major continents. The history of the Suez Canal proves that it has implications of strategic concepts; Suez Canal served as a militarily strategic asset. It was an object of war in 1967 and 1973 in Egypt. The Encyclopedia Britannica (2018) explains the British efforts to defend the Suez Canal from the forces of Nazi Germany and the BBC documentary 20th Century Battlefields episode describes how the Suez Canal was a strategic objective of nations engaged in war in the region. It definitely had profound effects on regional and global affairs. The Suez Canal project is a waterway linking the port city of 
Suez on the Red Sea to Port Said on the Mediterranean, saving countries' merchandise ships sailing around the Cape at the southern end of the African continent.

Originally the Suez Canal shares were owned by France and Egypt, but due to the downturn of the Egyptian economy in 1875 and the nationalist uprising in 1882 which threatened the stability of the canal zone, Great Britain found an opportunity to invade and conquer Egypt occupying the Suez Canal and buying all the Egyptian shares of the canal company. By this act, the British Royal Navy was provided quick access for its commercial ships to the British Commonwealth everywhere. Furthermore, the Suez Canal provided the Royal Navy the mobility to protect shipping and project sea power (SCA, 2018).

The 1888 Convention of Constantinople, which was held by the UK, France, the Russian Empire, Germany, Austro-Hungary, Italy, The Netherlands, Spain and the Ottoman Empire, came up with an agreement of the internationalization of the Suez Canal in the face of British occupation. The agreement permitted all nations' commercial ships the right to navigate through the Suez Canal in times of war and peace, with the condition that the British military would be existing by the canal.

"The convention allowed the canal to be closed only if it is necessary for Egypt's defense and the maintenance of public order" (Constantinople Convention, 1888). The Constantinople agreement was ignored by the British during World War I, which drove the Ottomans (led by German tacticians) to seize the Suez Canal and stop the British commercial ships from reaching their colonies. The attempt failed and the canal would continue to be a vital British asset for the rest of the war (Fielding, 2018). In the second World War, Italy and Germany launched an attack against Britain to expel England from Egypt. Again, this attempt failed and the Allies succeeded to push the attackers out of Northern Africa and kept the Suez Canal opened to serve their own interests (Encyclopedia Britannica, 2018).

In 1952, the Egyptian military officer "Gamal Abdel Nasser" led a nationalist coup which led to the end of the British occupation of Egypt but still maintained the control of the Suez Canal having military existence there per the 1888 Convention of Constantinople. Soon after, Nasser ordered the nationalization of the Suez Canal on July 26th, 1956 and Egypt got hold of all of the Suez Canal assets and settled the compensation for all its stakeholders.

The UK considered the nationalization of the canal a direct threat to their interests in the Middle East; while Israel saw the act of blockade Israeli ships from using the Gulf of Suez and the Gulf of Aqaba, a violation of the 1888 Convention of Constantinople; and France expressed its anger toward the nationalization as it saw its illegal seizure of a valuable property owned by French citizens. All that led to a coalition between England, France and Israel against Egypt. In 1956, the coalition military forces pushed into the Sinai Peninsula and retake the Suez Canal. Due to the pressure from the Soviet Union and the USA, the coalition withdrew from Egypt and the British troops were expelled from the canal zone leaving Egypt with sole control over the canal (US Office of the Historian, 2016). The Suez Canal was again a strategic objective of Egypt and Israel who were engaged in the 1967 and 1973 war. As a result of these wars, territorial changes found the place. In 1975, Israel and Egypt signed a peace agreement allowing for the demilitarization of the canal zone and the freedom of Israeli ships to navigate through the canal. In 1979 a US-facilitated peace treaty ended the Israeli presence in the Sinai Peninsula and returned the Sinai Peninsula to Egypt (McGuigan, 2007).

\section{The Suez Canal today}

Today (2018), the Suez Canal brings an annual income of $\$ 6 \mathrm{bn}$, which is a $\$ 500 \mathrm{~m}$ increase from the canal annual income of 2017. This rise in canal income is attributed to the expansion of the "New Suez Canal" that was completed in 2015. 
This expansion gives the opportunity to certain vessels that would normally navigate around the African continent to use the shortcut provided by Suez (Ahram Online, 2018).

According to Mr. Ashraf Salman the Investment Minister in 2015, the enlargement of the Suez Canal will improve the canal zone and would bring in $\$ 13 \mathrm{bn}$ annually. This will account for around 35\% of Egypt's economy (Farouk and Bushra, 2015).

Furthermore, the new logistical capabilities will facilitate trade between Mediterranean Europe and China, which has invested in the development of new container terminals in Port Said and new cargo terminals at Port of Adabiya at the southern end (Sari, 2017).

The US African Command (AFRICOM) stated in 2016 that there is a strategic partnership with Egypt and a mutual interest in protecting the Suez Canal against the Islamic State (ISIL Sinai), The US strategic interests in the Middle East, make the Suez Canal and its openness an important factor in American sea power (US Africa Command, 2016).

Egypt has been lately very keen about maximizing the length and depth of the Suez Canal waterway and that of course because of the increased volume of world trade and due to the Egyptian Government's will to raise the classification of the Suez Canal and increasing its competitiveness to other alternate routes. The enlargement of the Suez Canal will shorten the transiting and waiting time for vessels and will attract a bigger number of ships to use the canal. The ships will save a range of $23 \%$ to $88 \%$ of their target distance. Moreover, for the past four decades, the canal has been contributing to the Egyptian national income with a total amount of $91.7 \mathrm{bn}$ dollars.

Right after his inauguration in 2014, President Abd El Fattah El Sisi initiated the 21st-century project for the development of Egypt, "The New Suez Canal." The project is important for several reasons, as it will be a major contribution to the movement of the world's trade and it will attract investors from all over the globe promising them with huge financial returns. It will bring prosperity and peace not only to Egypt but also to the whole region. Domestically, the canal has been always one of the important sources of the national income of Egypt, as it was built in 1869.

The Suez Canal Authority has been very keen on executing and finishing the whole project within a single year, opposing the three years implementation period suggested by some studies. The idea behind the project is maximizing the length of the doubled parts of the canal and minimizing the waiting time at the anchorage area of transiting vessels. The project's estimated cost of 60bn EGP was raised by the Egyptian people in only 8 days.

This patriot act of the Egyptian people proved their strong will, faith in their leadership and their ability to achieve the impossible. On the 15th of August 2014 Prime Minister Eng. Ibrahim Mahaleb (at that time), issued investment certificates under the name of the "Suez Canal Investment Certificate" hoping to attract 60bn EGP for funding this huge national project.

National banks offered these certificates for an annual interest estimated at $12 \%$ to be disbursed every three months; while the original amount to be refunded after five years. The national banks managed to sell the certificates for 61bn EGP and the Suez Canal Authority won this big investment. The Suez Canal Authority started right-a-way working on the canal infrastructure and succeeded to open the new Tafreea project on August 6, 2015.

In the same year (2015) the canal authority obtained direct loans from banks amounting to $\$ 1.4 \mathrm{bn}$ to be able to pay off foreign companies operating in the project and to contribute to the foreign component of the new canal.

The execution of the project was cut short to one year as per the instructions of President Abd El-Fattah El-Sisi. The inauguration ceremony found the place exactly after one year [3].

\section{The research design and methodology}

The researcher used both qualitative research techniques in parallel with quantitative analysis to develop a more holistic view of the results. started by prospecting and seeking to 
acquire a more and deeper understanding of the studied concept via collecting using confirmatory methods and searching within secondary sources of information. The research studies have used the literature review to assist them in gaining a better insight into the topic being studied. To acquire accurate, factual and systematic data that can provide an actual picture of the concept being studied, as well as to describe the characteristics of sampling units, the research studies had to follow descriptive methods. As for the quantitative study, the researcher depended on mathematical methods, namely, statistics.

Methods used for data collection were mainly self-administered questionnaire, which contained 37 questions addressed to 384 participants working in two National Egyptian banks (Bank Misr and Al Ahly Bank) as these were the two main banks which issued the Suez Canal Investment certificates. In addition, the questionnaires were addressed to citizens who bought these certificates and officially participated in the New Suez Canal Project.

The scales that were used in the survey are the Likert scale and nominal scale. The Likert scale is the most fundamental and frequently used tool in educational and social science research because it helps a lot in the debates and controversies.

The sampling technique followed by the researchers was the non-probability judgmental sampling method, where the researcher selects units to be sampled based on his own existing knowledge or his professional judgment. Regarding the data coding, verification and entry, the researcher used the statistical package for social sciences (SPSS). The data verification to determine the distribution of answers based on the response of the respondents. Then, the Spearman correlation and the Cronbach's alpha test were used to measure the reliability of the statements to determine if there is a relationship between the dependent and the independent variables. In addition, the researcher used the regression analysis to identify the level of development of citizen participation initiatives, taking into account the factors which might interfere and affect citizens' initiatives of participation.

Finally, came the stage where the correlations are established. The researchers computed the statements by using Spearman and Pearson correlation test measuring both (Independent) and (dependent) variables.

\section{Testing research hypotheses}

H1. Transparency and disclosure of information increase the level of citizens' trust in their government.

H2. Citizens' trust in their government increases the level of participation in national projects.

H3. The PSM (Patriot Drive) is behind Egyptian Citizens' participation in financing the New Suez Canal.

H4. The High expected profits of the Suez Canal investment certificates was the driving force behind citizens' participation in the New Suez Canal project.

\section{Hypothesis 1}

Transparency and disclosure of information increase the level of citizens' trust in their government. In total, $92 \%$ of the participants agreed on the following statement: "The honesty of the Information provided by the government-supported citizen participation in the New Suez Canal project." The mean of 4.23 and the standard deviation of 0.84 .
Financing national projects

$\longrightarrow$


In total, 82.85 of the participants agreed on the following statement: "The more the citizen feels he/she is a member of his society, the more effective and efficient citizen participation will be." The mean of 4.22 and the standard deviation of 0.82 .

In total, $63.8 \%$ of the participants agreed on the following statement: "Egyptian citizens have proven trust in their leaders by contributing with 60m EGP in just 8 days for the New Suez Canal project." The mean of 3.80 and the standard deviation of 1.09.

In total, $48.4 \%$ of the participants agreed on the following statement: "We believe, Egypt has reached a milestone in establishing disclosure of information and information availability by implementing the New Suez Canal Project financed by its citizens." The mean of 3.41 and the standard deviation of 1.07 (see Appendix, p. \#).

The mean for all statements is above 3 , which indicates that all participants agree that "Transparency and disclosure of information increase the level of citizens' trust in their government." The standard deviation for all statements is less than 2 which means that the sample is homogenous with low variation.

$\left(R^{2}\right)$ show that the independent variable (transparency and disclosure of information increases the level of citizens' trust in their government.) explains (56.1\%) of the total variation in the dependent variable (the level of citizens' trust).

The independent variable (transparency and disclosure of information) $\mathrm{x}$ is a driving force for the dependent variable (the level of citizens' trust in their government) y as the value of " $t$ " (22.116) with a significant level less than (0.01).

To test the quality of the model as a whole (F-test) has a value (489.123) with a significant level less than (0.01) indicating goodness of fit of the model. $H 1$ is accepted.

\section{Hypothesis 2}

Citizens' trust in their government increases the level of participation in national projects. In total, $73 \%$ of the participants agreed on the following statement: "the existence of property rights was a profound element for facilitating and encouraging citizen participation in the Suez Canal project." The mean of 4.10 and the standard deviation of 0.85 .

In total, $73.7 \%$ of the participants agreed on the following statement: "the accountability of the government was a driving force for encouraging citizens to participate in financing the project." The mean of 4.05 and the standard deviation of 0.88 .

In total, $71.1 \%$ of the participants agreed on the following statement: "the transparency of the investment environment of the New Suez Canal project is attracting citizens to participate in financing it." The mean of 3.99 and the standard deviation of 0.95 .

In total, $66.7 \%$ of the participants agreed on the following statement:

The government's facilitation in providing citizens with the needed information, in addition to the openness of the relationship between the government and citizens are the main reason behind citizens' financial participation in national projects.

The mean of 3.77 and the standard deviation of 1.13 .

In total, $62.5 \%$ of the participants agreed on the following statement: "Citizens were encouraged to participate in financing the enlargement of the New Suez Canal because of the existence of fair independent auditing system of the project." The mean of 3.69 and the standard deviation of 1.19 .

The mean for all statements is above 3 , which indicates that all participants agree that "Citizens' trust in their government increases the level of participation in national projects." The standard deviation for all statements is less than 2 which means that the sample is homogenous with low variation. 
$\left(R^{2}\right)$ show that the independent variable (citizens' trust in their government) x explains $(37.5 \%)$ of the total variation in the dependent variable (the level of participation in the national project) $\mathrm{y}$ and the rest of the ratio, due to random error in the equation.

The independent variable (the citizens trust in their government) $\mathrm{x}$ has a significant effect on the dependent variable (the level of participation in the national project) $y$ as the value of " $t$ " (15.151) with a significant level less than (0.01).

To test the quality of the model as a whole (F-test) has a value (229.548) with a significant level less than (0.01) indicating goodness of fit of the model. H2 is accepted.

\section{Hypothesis 3}

The PSM (Patriot drive) is behind Egyptian citizens' participation in financing the new Suez Canal. In total, $92 \%$ of the participants agreed on the following statement: "The Egyptian citizens' participation in the New Suez Canal is reflecting their patriot sense toward their country. The mean of 4.63 and the standard deviation of 0.64 .

In total, $87 \%$ of the participants agreed on the following statement: "Egyptian citizens have proven to be a patriot by contributing with 60m EGP in just 8 days for the New Suez Canal project." The mean of 4.43 and the standard deviation of 0.78 .

In total, 82.3 of the participants agreed on the following statement: "The more the citizen feels he/she is a member of his society, the more effective and efficient citizen participation will be." The mean of 4.22 and the standard deviation of 0.82 .

In total, $63.8 \%$ of the participants agreed on the following statement: "Egyptian citizens have proven trust in their leaders by contributing with 60m EGP in just 8 days for the New Suez Canal project." The mean of 3.80 and the standard deviation of 1.09.

The mean for all statements is above 3 , which indicates that all participants agree that "The PSM (Patriot Drive) is behind Egyptian Citizens' participation in financing the New Suez Canal" The standard deviation for all statements is less than 2 which means that the sample is homogenous with low variation.

$\left(R^{2}\right)$ show that the independent variable (The PSM [Patriot Drive] x explains (54.0\%) of the total variation in the dependent variable (Egyptian Citizens' participation in financing the New Suez Canal) y and the rest of the ratio, due to random error in the equation.

The independent variable (The PSM [Patriot Drive]) $\mathrm{x}$ has a significant effect on the dependent variable (Egyptian Citizens' participation in financing the New Suez Canal) y) as the value of " $t$ " (21.186) with significant level less than $(0.01)$.

To test the quality of the model as a whole ( $F$-test) has a value (448.860) with a significant level less than (0.01) indicating goodness of fit of the model. H3 is accepted.

\section{Hypothesis 4}

The high expected profits of the Suez Canal investment certificates was the driving force behind citizens' participation in the new Suez Canal project. In total, 84.9\% of the participants agreed on the following statement: "The belief that the financial participation in the New Suez Canal project is a good investment was the reason behind citizen participation." The mean of 4.40 and the standard deviation of 0.79 .

In total, $63.3 \%$ of the participants agreed on the following statement: "The increase of the interest rates of Suez Canal Investment Certificate $(12 \%)$ was the main reason for the Egyptian citizens' participation in this national project." The mean of 3.74 and the standard deviation of 1.06 .

In total, $45.6 \%$ of the participants agreed on the following statement: "The main driving force behind the citizen participation in the New Suez Canal project is its expected high revenue and profit." The mean of 3.15 and the standard deviation of 1.12 . 
The mean for all statements is above 3, which indicates that all participants agree that "The High expected profits of the Suez Canal investment certificates was the driving force behind citizens' participation in the New Suez Canal project." The standard deviation for all statements is less than 2 which means that the sample is homogenous with low variation.

$\left(R^{2}\right)$ show that the independent variable (The High expected profits of the Suez Canal investment certificates) $\mathrm{x}$ explains $(55.3 \%$ ) of the total variation in the dependent variable (citizens' participation in the New Suez Canal project). $\mathbf{y}$ and the rest of the ratio, due to random error in the equation.

The independent variable (The High expected profits of the Suez Canal investment certificates) $\mathrm{x}$ has a significant effect on the dependent variable (citizens' participation in the New Suez Canal project) y as the value of " $t$ " (21.752) with significant level less than (0.01).

To test the quality of the model as a whole ( $F$-test) has a value (473.141) with a significant level less than (0.01) indicating goodness of fit of the model. $H 4$ is accepted.

\section{Conclusion}

- Looking at the empirical results, $H 1$ and $H 2$ have been accepted as trust, transparency and citizen participation proved to be important pillars of building a participatory government. Transparency based on clear correct and qualified information is essential for building and developing a bridge of trust between government and citizens.

- There is a strong and positive relationship between democracy, transparency, citizens' participation and the increase of the level of trust in government.

- Citizen participation in government policies and decisions is definitely building public trust and narrows the gap between governments and citizens.

- If citizens are content with their public participation and government's decision outcomes, their confidence in the policymakers will increase and their level of participation will go up.

- E-government is considered one of the very important channels of communication between citizens and their government, which makes them believe that the government is capable of solving problems and increases the level of interaction and ultimately the political trust.

- $H 3$ and $H 4$ are accepted and the statistical study revealed dual results regarding the motive of citizens' financial participation in the New Suez Canal project, for example:

The statistical results of the following statement: "Egyptian citizens have proven being a patriot by contributing with 60m EGP in just 8 days for the New Suez Canal project," proved that $87 \%$ of the participants agreed on it with the mean of 4.43 , which indicates the majority of participants agree on that statement and the standard deviation of 0.78 , which means that the sample is homogenous with low variation (see appendix Table A4, Statement 1).

The statistical results of the following statement: "The belief that the financial participation in the New Suez Canal project is a good investment was the reason behind citizen participation," proved that $84.9 \%$ agreed on it with the mean of 4.40 , which indicates the majority of participants agree on that statement and the standard deviation of 0.79 , which means that the sample is homogenous with low variation (see appendix Table A5, Statement 2). 
The explanation of the above-mentioned results

Right after the 2011 up-rise, Egyptian citizens were overwhelmed with patriot emotions and feelings pushing them to participate in national projects. At the same time, this patriot drive was weakened and moderated by the "performance-based rewards and citizens" selfinterests' pushed by the Egyptian government (offering a high-interest rate at that time for Suez Canal Certificates).

Huang and Feeney (2016) assured that performance-based rewards in our study (highinterest rate) is playing a role in moderating the PSM (patriot sense) Actually, both had a positive impact on citizens' participation in financing the New Suez canal. citizens were initially filled with the patriot drive and then this drive was moderated by the high-interest rate offered by the government (performance-based rewards)

- There were certain questions addressed to the participants to relate the theory of PSM and the theory of performance-based rewards to the statistical results at the end of the study. These questions such as "The Egyptian citizens' participation in the New Suez Canal is reflecting their patriot sense toward their country" and "I believe in putting duty before self." (PSM) (Table A4 in appendix) as for (performance-based rewards): "The belief that the financial participation in the New Suez Canal project is a good investment was the reason behind citizen participation." (Table A5 in appendix) Using descriptive and multivariate statistics, the analyzes conclude that there is a positive relationship between performancebased rewards and encouraging citizen participation in government's projects; and also there is a positive relationship between PSM (the patriot sense) and encouraging citizen participation in government's projects. The dichotomy and of the two results have been explained in the above-mentioned part ( $H 3$ and $H 4$ ).

Hence, citizens might be motivated to participate in national projects triggered by many factors: public service drive - patriotism or self-interest.

\section{Further research}

Future research should assess whether PSM will enable more implementable decisions? Would different participatory actions result differently in other circumstances? Also, do individuals' levels of PSM vary over time, and if so, what patterns exist? Finally, the researcher needs to find ways to test PSM against various motives such as self-interest, which needs to be confirmed empirically.

\section{Recommendations}

- Public managers and political leaders should adopt strategies that enforce and complement citizens' PSM to participate in governments' decisions and programs.

- Policymakers and leaders should be aware of the multi-facet nature of citizens' motivation to participate in government decision-making or in national projects (patriotism - self-interest - a drive of civic duty - social and public service drive). Their policies and strategies should be tailored accordingly.

- Decision-makers in the central government should work local and regional authorities to update and improve local and regional regulations concerning the participation of citizens in local public life and promote a culture of democratic participation shared by communities and local authorities.
Financing national projects 


\section{REPS}

- Central government should embrace and adopt an approach to citizens' participation with consideration to representative democracy and to the forms of direct participation in decision-making.

- Embracing governance framework at all governmental levels is highly recommended and putting great efforts into improving citizens' education, too; in addition to incorporating the objective of promoting awareness of the responsibilities of each individual in a democratic society.

- Government should ensure and facilitate citizens' accessibility to data and information concerning local and central affairs.

- Promoting dialogue between citizens and local elected representatives and make sure that citizens can play a direct part in decision-making.

\section{Notes}

1. The Arnstein ladder provides an eight point scale for assessing a citizen's expectations of participation in governments' policies and decisions.

3. www.suezcanal.gov.eg

\section{References}

Abelson, J. and Gauvin, F.P. (2006), "Assessing the impacts of public participation: concepts. Evidence and policy implications", Canadian Policy Research Networks Research Report P/06, Ottawa.

Ahram Online (2018), "\$500m increase in Suez Canal annual revenues in 2018: SCA - politics - Egypt Ahram online", Retrieved November 29, 2018, available at: http://english.ahram.org.eg/ NewsContent/1/64/315960/Egypt/Politics-/m-increase-in-

Almond, G.A. and Coleman, J.S. (1960), "The politics of the developing areas (Princeton)”, Comparative Politics: A Developmental Approach (Boston, 1966).

Arnstein, S.R. (1969), "A ladder of citizen participation”, Journal of the American Institute of Planners, Vol. 35 No. 4, pp. 216-224.

Blakeley, G. (2010), "Governing ourselves: citizen participation and governance in Barcelona and Manchester", International Journal of Urban and Regional Research, Vol. 34 No. 1, pp. 130-145.

Brabham, D.C. (2009), "Crowdsourcing the public participation process for planning projects", Planning Theory, Vol. 8 No. 3, pp. 242-262.

Brewer, G.A., Selden, S.C. and Facer, R.L. II, (2000), "Individual conceptions of public service motivation", Public Administration Review, Vol. 60 No. 3, pp. 254-264.

Carreira, V., Machado, J. and Vasconcelos, L. (2016), "Engaging citizen participation - a result of trusting governmental institutions and politicians in the Portuguese democracy", Social Sciences, Vol. 5 No. 3, p. 40.

Constantinople Convention (1888), "Convention of constantinople treaty".

Dutrénit, G. and Suárez, M. (2017), "Involving stakeholders in policymaking: tensions emerging from a public dialogue with knowledge-based entrepreneurs", Science and Public Policy, Advance Article, No. 3, pp. 1-350.

Duţu, A. and Diaconu, M. (2017), "Community participation for an open public administration: empirical measurements and conceptual framework design", Cogent Business and Management, Vol. 4 No. 1, p. 1287980. 
Encyclopedia Britannica (2018). "World war II - other fronts, 1940-41”, Retrieved November 30, 2018, available at: www.britannica.com/event/World-War-II

Epstein, J.L., Sanders, M.G., Sheldon, S.B., Simon, B.S., Salinas, K.C., Jansorn, N.R. . . . and Hutchins, D.J. (2018), School, Family, and Community Partnerships: Your Handbook for Action, Corwin Press.

Financing national projects

Fahmy, D. and Faruqi, D. (Eds) (2017), Egypt and the Contradictions of Liberalism: Iliberal Intelligentsia and the Future of Egyptian Democracy, Oneworld Publications.

Farouk, E. and Bushra, S. (2015), "Egypt sees Suez Canal zone making up 30-35 pct of economy -minister", Reuters, available at: www.reuters.com/article/egypt-canalministeridUSL5N0W74WT20150305

Fielding, M. (2018), "Busting Beersheba: Australians in the campaign to defeat the Ottoman empire", Presented at the Military History and Heritage, Camberwell, Victoria, p. 9.

Fuchs, D. and Roller, E. (1994), Cultural Conditions of the Transition to Liberal Democracy in Central and Eastern Europe, WZB, Berlin.

Hearst, D. and Hussein, A. (2012), "Egypt's supreme court dissolves parliament and outrages islamists", The Guardian, available at: www.theguardian.com/world/2012/jun/14/egyptparliament-dissolved-supreme-court

Hobson, C. (2009), "The limits of liberal-democracy promotion", Alternatives: Global, Local, Political, Vol. 34 No. 4, pp. 383-405.

Huang, W.L. and Feeney, M.K. (2016), "Citizen participation in local government decision making: the role of manager motivation", Review of Public Personnel Administration, Vol. 36 No. 2, pp. 188-209.

Kim, B.S. and Kim, J.H (2007), "Increasing trust in government through more participatory and transparent government", in Proceedings of the Capacity-development Workshop on Restoring Trust in Government through Public Sector Innovations, United Nations Public Administration Network, New York.

Kim, S. and Lee, J. (2017), "Citizen participation and transparency in local government: do participation channels and policy making phases matter?", Proceedings of the 50th HI International Conference on System Sciences.

Lee, Y. and Park, T. (2009), "Civil participation in the making of a new regulatory state ein Korea: 19982008”, Korea Observer, Vol. 40 No. 3, p. 461.

Lee, H.J., Oh, H.G. and Park, S.M. (2019), "Do trust and culture matter for public service motivation development? Evidence from public sector employees in Korea”, Public Personnel Management, Vol. 49 No. 2, p. 0091026019869738.

Lussier, D.N. (2011), "Activating democracy: political participation and the fate of regime change in russia and Indonesia”, Doctoral dissertation, UC Berkeley.

McGuigan, P. (2007), BBC-20th Century Battlefields - 1973 Middle East, British Broadcasting Company, available at: www.youtube.com/watch? $\mathrm{v}=43 \mathrm{FJI} 3 \mathrm{hw} 0 \mathrm{pU}$

Michels, A. and De Graaf, L. (2010), "Examining citizen participation: local participatory policy making and democracy", Local Government Studies, Vol. 36 No. 4, pp. 477-491.

Pandey, S.K. and Stazyk, E.C. (2008), "Antecedents and correlates of public service motivation", Motivation in Public Management: The Call of Public Service, pp. 101-117.

Park, J.H. (2016), “The great recession, citizen participation, fiscal retrenchment, and fiscal recovery: the application of a democratic fiscal decision making system", Doctoral dissertation, University of Nebraska at Omaha.

Robert Forster (2017), "Egypt case study (Inclusion and Egypt's Political Transition)", University of Edinburgh, January, 2017.

Rothstein, B. and Stolle, D. (2003), "Social capital, impartiality and the welfare state: an institutional approach", in Hooghe, M. and Stolle, D. (Eds), Generating Social Capital: Civil Society and Institutions in Comparative Perspective, Palgrave, New York, NY, pp. 191-210. 
Sari, M. (2017), "The confucius institute at Suez Canal university: a tool in China's public diplomacy", available at: http://lup.lub.lu.se/student-papers/record/8924607

SCA (2018), "Suez canal Authority - Canal history", Retrieved November 29, 2018, available at: www. suezcanal.gov.eg:443/English/About/SuezCanal/Pages/CanalHistory.aspx

Suez-Canal-annual-revenues-in-SCA-aspx, available at: https://mawdoo3.com or www.suezcanal.gov. eg or www.elfagr.com/3409245

US Africa Command (2016), "United States African command - hearing before the committee on armed services", United States Senate. Retrieved November 29, 2018, available at: www.gpo.gov/fdsys/ pkg/CHRG-114shrg25682/html/CHRG-114shrg25682.htm

US Office of the Historian (2016), "Milestones: 1953-1960 - Office of the historian”, December 1, 2018, available at: https:/history.state.gov/milestones/1953-1960/suez

Yang, K. and Callahan, K. (2007), "Citizen involvement efforts and bureaucratic responsiveness: participatory values, stakeholder pressures, and administrative practicality", Public Administration Review, Vol. 67 No. 2, pp. 249-264.

\section{Further reading}

Axelsson, K., Melin, U. and Lindgren, I. (2010), "Exploring the importance of citizen participation and involvement in e-government projects: practice, incentives, and organization", Transforming Government: People, Process and Policy, Vol. 4 No. 4, pp. 299-321.

Connor, D.M. (1988), “A new ladder of citizen participation”, National Civic Review, Vol. 77 No. 3, pp. 249-257.

Dennett, T. (1935), “Mahan's ‘the problem of Asia”, Foreign Affairs, Vol. 13 No. 3.

Hallman, H. (1972), "Federally financed citizen participation”, Public Administration Review, Vol. 32, pp. 421-427, doi: $10.2307 / 975012$.

Park, S.M. and Rainey, H.G. (2008), "Leadership and public service motivation in US federal agencies", International Public Management Journal, Vol. 11 No. 1, pp. 109-142.

Sanchez, R.M.P. (2019), "The strategic and geopolitical implications of canals”.

Tessler, M. (2002), "Islam and democracy in the Middle East: the impact of religious orientations on attitudes toward democracy in four Arab countries", Comparative Politics, Vol. 34 No. 3, pp. 337-354.

Yazaki, A. (2014), What Egypt Tells Us about the State of Democracy, United Nations University, July 2014.

\section{Corresponding author}

Zeinab Abbas Zaazou can be contacted at: zabbas@msa.eun.eg 
Appendix A

Financing

national

Demographic characteristics

projects

\begin{tabular}{|c|c|c|c|c|c|}
\hline No. & 1-gender & Frequency & Present & Rank & \\
\hline 1 & Male & 195 & 50.8 & 1 & \\
\hline $\begin{array}{l}2 \\
\text { Total }\end{array}$ & Female & $\begin{array}{l}189 \\
384\end{array}$ & $\begin{array}{c}49.2 \\
100\end{array}$ & 2 & \\
\hline \multicolumn{6}{|c|}{ 2-age group years } \\
\hline 1 & Less than 30 & 68 & 17.7 & 3 & \\
\hline 2 & 30 - less than 40 & 124 & 32.3 & 2 & \\
\hline 3 & 40 - less than 50 & 155 & 40.4 & 1 & \\
\hline 4 & More than 50 & 37 & 9.6 & 4 & \\
\hline Total & & 384 & 100 & - & \\
\hline \multicolumn{6}{|l|}{ 3-education } \\
\hline 1 & Less than university education & 120 & 31.3 & 2 & \\
\hline 2 & University graduate & 237 & 61.7 & 1 & \\
\hline 3 & Post graduate & 27 & 7.0 & 3 & \\
\hline Total & & 384 & 100 & - & \\
\hline 4-occupation & & & & & Table A1. \\
\hline 1 & Public sector & 108 & 28.1 & 2 & Frequency \\
\hline 2 & Private sector & 197 & 51.3 & 1 & distribution of the \\
\hline 3 & Free lancer & 79 & 20.6 & 3 & demographic \\
\hline Total & & 384 & 100 & - & characteristics \\
\hline
\end{tabular}




\section{REPS}

Descriptive statistics

\begin{tabular}{|c|c|c|c|c|c|c|c|c|c|c|}
\hline & Phrases & & $\begin{array}{l}\text { Strongly } \\
\text { agree }\end{array}$ & agree & Neutral & disagree & $\begin{array}{l}\text { Strongly } \\
\text { disagree }\end{array}$ & Mean & Std. & $\mathrm{R}$ \\
\hline & $\begin{array}{l}\text { 1-We believe Egypt has } \\
\text { reached a milestone in } \\
\text { establishing disclosure of } \\
\text { information and information } \\
\text { availability by implementing } \\
\text { the New Suez Canal Project } \\
\text { financed by its citizens }\end{array}$ & $\begin{array}{l}F \\
\%\end{array}$ & $\begin{array}{l}67 \\
17.4\end{array}$ & $\begin{array}{r}119 \\
31\end{array}$ & $\begin{array}{l}112 \\
29.2\end{array}$ & $\begin{array}{l}75 \\
19.5\end{array}$ & $\begin{array}{c}11 \\
2.9\end{array}$ & 3.41 & 1.07 & 4 \\
\hline & $\begin{array}{l}\text { 2-Egyptian citizens have } \\
\text { proven trust in their leaders } \\
\text { by contributing with } 60 \mathrm{~m} \\
\text { EGP in just } 8 \text { days for the } \\
\text { New Suez Canal project }\end{array}$ & $\begin{array}{l}F \\
\%\end{array}$ & $\begin{array}{c}124 \\
32.3\end{array}$ & $\begin{array}{c}121 \\
31.5\end{array}$ & $\begin{array}{l}90 \\
23.4\end{array}$ & $\begin{array}{l}36 \\
9.4\end{array}$ & $\begin{array}{c}13 \\
3.4\end{array}$ & 3.80 & 1.09 & 3 \\
\hline $\begin{array}{l}\text { Table A2. } \\
\text { Descriptive } \\
\text { atistical dimension }\end{array}$ & $\begin{array}{l}\text { 3-The more the citizen feels he/ } \\
\text { she is a member of his } \\
\text { society, the more effective } \\
\text { and efficient citizen } \\
\text { participation will be }\end{array}$ & $\begin{array}{l}F \\
\%\end{array}$ & $\begin{array}{c}166 \\
43.2\end{array}$ & $\begin{array}{c}152 \\
39.6\end{array}$ & $\begin{array}{l}50 \\
13\end{array}$ & $\begin{array}{c}16 \\
4.2\end{array}$ & - & 4.22 & 0.82 & 2 \\
\hline $\begin{array}{l}\text { disclosure of } \\
\text { information increases } \\
\text { citizens' level of trust }\end{array}$ & $\begin{array}{l}\text { 4-The honesty of the } \\
\text { Information provided by the } \\
\text { government-supported } \\
\text { citizen participation in the } \\
\text { New Suez Canal project }\end{array}$ & $\begin{array}{l}F \\
\%\end{array}$ & $\begin{array}{c}172 \\
71.4\end{array}$ & $\begin{array}{c}134 \\
20.6\end{array}$ & $\begin{array}{l}68 \\
7.6\end{array}$ & $\begin{array}{c}10 \\
0.5\end{array}$ & - & 4.23 & 0.84 & 1 \\
\hline n their government" & Mean average & & & & & & & 3.93 & 0.41 & - \\
\hline
\end{tabular}




\begin{tabular}{|c|c|c|c|c|c|c|c|c|c|c|}
\hline Phrases & & $\begin{array}{l}\text { Strongly } \\
\text { agree }\end{array}$ & agree & Neutral & disagree & $\begin{array}{l}\text { Strongly } \\
\text { disagree }\end{array}$ & Mean & Std. & $\mathrm{R}$ & national \\
\hline $\begin{array}{l}\text { 1-The transparency of the } \\
\text { investment environment of } \\
\text { the New Suez Canal project } \\
\text { is attracting citizens to } \\
\text { participate in financing it }\end{array}$ & $\begin{array}{l}F \\
\%\end{array}$ & $\begin{array}{c}139 \\
36.2\end{array}$ & $\begin{array}{c}134 \\
34.9\end{array}$ & $\begin{array}{l}84 \\
21.9\end{array}$ & $\begin{array}{c}24 \\
6.3\end{array}$ & $\begin{array}{l}3 \\
0.8\end{array}$ & 3.99 & 0.95 & 3 & \\
\hline $\begin{array}{l}\text { 2-The accountability of the } \\
\text { government was a driving } \\
\text { force for encouraging } \\
\text { citizens to participate in } \\
\text { financing the project }\end{array}$ & $\begin{array}{l}F \\
\%\end{array}$ & $\begin{array}{l}141 \\
36.7\end{array}$ & $\begin{array}{r}142 \\
37\end{array}$ & $\begin{array}{l}82 \\
21.4\end{array}$ & $\begin{array}{c}19 \\
4.9\end{array}$ & $\overline{-}$ & 4.05 & 0.88 & 2 & \\
\hline $\begin{array}{l}\text { 3-The existence of property } \\
\text { rights was a profound } \\
\text { element for facilitating and } \\
\text { encouraging citizen } \\
\text { participation in the "Suez } \\
\text { Canal Project" }\end{array}$ & $\begin{array}{l}F \\
\%\end{array}$ & $\begin{array}{l}155 \\
40.4\end{array}$ & $\begin{array}{c}125 \\
32.6\end{array}$ & $\begin{array}{l}90 \\
23.4\end{array}$ & $\begin{array}{c}14 \\
3.6\end{array}$ & $\begin{array}{l}- \\
-\end{array}$ & 4.10 & 0.85 & 1 & \\
\hline $\begin{array}{l}\text { 4-Citizens were encouraged to } \\
\text { participate in financing the } \\
\text { enlargement of the New Suez } \\
\text { Canal because of the } \\
\text { existence of a fair } \\
\text { independent auditing system } \\
\text { of the project }\end{array}$ & $\begin{array}{l}F \\
\%\end{array}$ & $\begin{array}{c}116 \\
30.2\end{array}$ & $\begin{array}{c}124 \\
32.3\end{array}$ & $\begin{array}{l}80 \\
20.8\end{array}$ & $\begin{array}{l}37 \\
9.6\end{array}$ & $\begin{array}{r}27 \\
7\end{array}$ & 3.69 & 1.19 & 5 & \\
\hline $\begin{array}{l}\text { 5-The government's } \\
\text { facilitation in providing } \\
\text { citizens with the needed } \\
\text { information, in addition to } \\
\text { the openness of the } \\
\text { relationship between the } \\
\text { government and citizens are } \\
\text { the main reasons behind } \\
\text { citizens' financial } \\
\text { participation in national } \\
\text { projects }\end{array}$ & $\begin{array}{l}F \\
\%\end{array}$ & $\begin{array}{c}116 \\
30.2\end{array}$ & $\begin{array}{c}140 \\
36.5\end{array}$ & $\begin{array}{l}72 \\
18.8\end{array}$ & $\begin{array}{l}35 \\
9.1\end{array}$ & $\begin{array}{c}21 \\
5.5\end{array}$ & 3.77 & 1.13 & 4 & $\begin{array}{r}\text { Table A3. } \\
\text { Descriptive } \\
\text { statistical dimension } \\
\text { of "citizens' trust in } \\
\text { their government } \\
\text { increases the level of } \\
\text { participation in }\end{array}$ \\
\hline Mean average & & & & & & & 3.60 & 0.51 & - & national projects" \\
\hline
\end{tabular}




\section{REPS}

Table A4.

Descriptive

statistical dimension

of "the Patriot drive

is behind Egyptian

citizens' participation

in financing the new

Suez Canal"

\begin{tabular}{|c|c|c|c|c|c|c|c|c|c|}
\hline Phrases & & $\begin{array}{c}\text { Strongly } \\
\text { agree }\end{array}$ & agree & Neutral & disagree & $\begin{array}{l}\text { Strongly } \\
\text { disagree }\end{array}$ & Mean & Std. & $\mathrm{R}$ \\
\hline $\begin{array}{l}\text { 1-Egyptian citizens have } \\
\text { proven to be a patriot by } \\
\text { contributing with } 60 \mathrm{~m} \mathrm{EGP} \\
\text { in just } 8 \text { days for the New } \\
\text { Suez Canal project }\end{array}$ & $\begin{array}{l}F \\
\%\end{array}$ & $\begin{array}{l}225 \\
58.6\end{array}$ & $\begin{array}{l}109 \\
28.4\end{array}$ & $\begin{array}{l}40 \\
10.4\end{array}$ & $\begin{array}{l}10 \\
2.6\end{array}$ & - & 4.43 & 0.78 & 2 \\
\hline $\begin{array}{l}\text { 2-Egyptian citizens have } \\
\text { proven trust in their leaders } \\
\text { by contributing with } 60 \mathrm{~m} \\
\text { EGP in just } 8 \text { days for the } \\
\text { New Suez Canal project }\end{array}$ & $\begin{array}{l}F \\
\%\end{array}$ & $\begin{array}{c}124 \\
32.3\end{array}$ & $\begin{array}{l}121 \\
31.5\end{array}$ & $\begin{array}{l}90 \\
23.4\end{array}$ & $\begin{array}{l}36 \\
9.4\end{array}$ & $\begin{array}{c}13 \\
3.4\end{array}$ & 3.80 & 1.09 & 4 \\
\hline $\begin{array}{l}\text { 3-The more the citizen feels he/ } \\
\text { she is a member of his } \\
\text { society, the more effective } \\
\text { and efficient citizen } \\
\text { participation will be }\end{array}$ & $\begin{array}{l}F \\
\%\end{array}$ & $\begin{array}{l}166 \\
50.3\end{array}$ & $\begin{array}{r}152 \\
32\end{array}$ & $\begin{array}{l}50 \\
13.3\end{array}$ & $\begin{array}{c}16 \\
4.4\end{array}$ & $\begin{array}{l}- \\
-\end{array}$ & 4.22 & 0.82 & 3 \\
\hline $\begin{array}{l}\text { 4-I believe in putting duty } \\
\text { before self. }\end{array}$ & $\begin{array}{l}F \\
\%\end{array}$ & $\begin{array}{l}67 \\
17.4\end{array}$ & $\begin{array}{r}119 \\
31\end{array}$ & $\begin{array}{c}112 \\
29.2\end{array}$ & $\begin{array}{l}75 \\
19.5\end{array}$ & $\begin{array}{c}11 \\
2.9\end{array}$ & 3.41 & 1.07 & 5 \\
\hline $\begin{array}{l}\text { 5-The Egyptian citizens' } \\
\text { participation in the New } \\
\text { Suez Canal is reflecting their } \\
\text { patriot sense toward their } \\
\text { country }\end{array}$ & $\begin{array}{l}F \\
\%\end{array}$ & $\begin{array}{l}274 \\
71.4\end{array}$ & $\begin{array}{l}79 \\
20.6\end{array}$ & $\begin{array}{c}29 \\
7.6\end{array}$ & $\begin{array}{l}2 \\
0.5\end{array}$ & - & 4.63 & 0.64 & 1 \\
\hline Mean average & & & & & & & 3.93 & 0.41 & - \\
\hline
\end{tabular}

Table A5.

Descriptive

statistical dimension of "the high expected profits of the Suez Canal investment certificates was the driving force behind citizens' participation in the new Suez Canal project"

\begin{tabular}{|c|c|c|c|c|c|c|c|c|c|}
\hline Phrases & & $\begin{array}{l}\text { Strongly } \\
\text { agree }\end{array}$ & agree & Neutral & disagree & $\begin{array}{l}\text { Strongly } \\
\text { disagree }\end{array}$ & Mean & Std. & $\mathrm{R}$ \\
\hline $\begin{array}{l}\text { 1-The increase of the interest } \\
\text { rates of the Suez Canal } \\
\text { Investment Certificate }(12 \%) \\
\text { was the main reason for the } \\
\text { Egyptian citizens' } \\
\text { participation in this national } \\
\text { project }\end{array}$ & $\begin{array}{l}F \\
\%\end{array}$ & $\begin{array}{c}109 \\
28.4\end{array}$ & $\begin{array}{c}134 \\
34.9\end{array}$ & $\begin{array}{l}75 \\
19.5\end{array}$ & $\begin{array}{l}64 \\
16.7\end{array}$ & $\begin{array}{l}2 \\
0.5\end{array}$ & 3.74 & 1.06 & 2 \\
\hline $\begin{array}{l}\text { 2-The belief that financial } \\
\text { participation in the New } \\
\text { Suez Canal project is a good } \\
\text { investment was the reason } \\
\text { behind citizen participation }\end{array}$ & $\begin{array}{l}F \\
\%\end{array}$ & $\begin{array}{l}221 \\
57.6\end{array}$ & $\begin{array}{c}105 \\
27.3\end{array}$ & $\begin{array}{l}50 \\
13\end{array}$ & $\begin{array}{l}8 \\
2.1\end{array}$ & - & 4.40 & 0.79 & 1 \\
\hline $\begin{array}{l}\text { 3-The main driving force } \\
\text { behind the citizen } \\
\text { participation in the New } \\
\text { Suez Canal project is its } \\
\text { expected high revenue and } \\
\text { profit }\end{array}$ & $\begin{array}{l}F \\
\%\end{array}$ & $\begin{array}{l}35 \\
9.1\end{array}$ & $\begin{array}{l}140 \\
36.5\end{array}$ & $\begin{array}{l}88 \\
22.9\end{array}$ & $\begin{array}{l}89 \\
23.2\end{array}$ & $\begin{array}{c}32 \\
8.3\end{array}$ & 3.15 & 1.12 & 3 \\
\hline Mean average & & & & & & & 3.48 & 0.47 & - \\
\hline
\end{tabular}




\begin{tabular}{lcccccc}
\hline \multirow{2}{*}{ Independent variables } & \multicolumn{4}{c}{$t$. test } & \multicolumn{2}{c}{ F. test } \\
& $\beta$ & Value & Sig. & Value & Sig. & $\mathrm{R}^{2}$ \\
\hline Constant & 0.737 & 5.529 & $0.01^{* * *}$ & 544.468 & $0.01^{* *}$ & $58.8 \%$ \\
The transparency and disclosure of information & 0.767 & 23.334 & $0.01^{* *}$ & & &
\end{tabular}

Table A6.

The transparency and disclosure of information increases the level of citizens trust in their government by using linear regression

Note: ${ }^{* *}$ significant level 0.01

Table A7.

Citizens' trust in their government

\begin{tabular}{lcccccc} 
& \multicolumn{4}{c}{$t$. test } & \multicolumn{2}{c}{ F. test } \\
Independent variables & $\beta$ & Value & Sig. & Value & Sig. & $\mathrm{R}^{2}$ \\
\hline Constant & 1.877 & 13.271 & $0.01^{* * *}$ & 229.548 & $0.01^{* *}$ & $37.5 \%$ \\
The citizens trust in their government & 0.613 & 15.151 & $0.01^{* *}$ & & &
\end{tabular}
increases the level of participation in a national project by using linear regression

Note: ** significant level 0.01

Table A8.

\begin{tabular}{|c|c|c|c|c|c|c|}
\hline \multirow[b]{2}{*}{ Independent variables } & \multirow[b]{2}{*}{$\beta$} & \multicolumn{2}{|c|}{$t$. test } & \multicolumn{2}{|c|}{ F. test } & \multirow[b]{2}{*}{$\mathrm{R}^{2}$} \\
\hline & & Value & Sig. & Value & Sig. & \\
\hline $\begin{array}{l}\text { Constant } \\
\text { The high expected profits of the Suez }\end{array}$ & 1.538 & 12.844 & $0.01^{* *}$ & 448.860 & $0.01^{* * *}$ & $54.0 \%$ \\
\hline Canal investment certificates & 0.735 & 21.186 & $0.01^{\text {*** }}$ & & & \\
\hline
\end{tabular}

The public service motivation PSM (patriot drive) is behind Egyptian citizens' participation in financing the new Suez Canal

Note: * ${ }^{*}$ significant level 0.01

Table A9.

The high expected profits of the Suez Canal investment certificates was the driving force behind citizens' participation in the New Suez Canal project

Note: * ${ }^{*}$ significant level 0.01

\begin{tabular}{cccccc} 
& \multicolumn{2}{c}{$t$ t. test } & \multicolumn{2}{c}{ F. test } & \\
$\beta$ & Value & Sig. & Value & Sig. & $\mathrm{R}^{2}$ \\
\hline 1.590 & 14.635 & $0.01^{* * *}$ & & & \\
0.744 & 21.752 & $0.01^{* *}$ & 473.141 & $0.01^{* *}$ & $55.3 \%$
\end{tabular}

